\title{
MENYIKAPI LEMAHNYA GELIAT PUBLIKASI ILMIAH DI KOPERTIS WILAYAH XII, MALUKU DAN MALUKU UTARA
}

\author{
Ricardo Freedom Nanuru \\ Dosen Kopertis Wilayah XII, dpk pada Universitas Halmahera
}

\section{Pengantar}

Beberapa waktu lalu saat terjadi suksesi pemilihan rektor di Universitas Kristen Indonesia Maluku (UKIM) Ambon, penulis pernah menulis artikel atau lebih tepatnya sumbang saran terkait perkembangan pendidikan tinggi, lebih khusus di kalangan kampus tersebut. Beberapa hal yang dibahas antara lain seputar disiplin pegawai, kinerja penelitian dan pengabdian kepada masyarakat yang dilakukan dosen, kesejahteraan pegawai (baik dosen maupun staf administrasi), peningkatan kapasitas dosen dan staf, serta beberapa hal lainnya. Mengapa penulis mengemukakan hal ini? Jawabannya sederhana: penulis telah mencermati hal-hal ini sejak lama dan berusaha memperbaikinya. Perihal memperbaiki di sini tidaklah semudah membalik telapak tangan. Hal ini membutuhkan perhatian khusus, terlebih dari unsur pimpinan tertinggi. Dengan ketegasan dan disiplin mematuhi semua aturan yang ditetapkan, baik di tingkat internal universitas maupun di tingkat kopertis dan dikti, niscaya sebuah universitas akan terpacu untuk maju dan menjawab tantangan perubahan yang semakin melaju.

Dinamika perkembangan pendidikan tinggi di Indonesia sejak perubahan Kementerian Pendidikan dan Kebudayaan (Kemendikbud) menjadi Kementerian Riset Teknologi dan Pendidikan Tinggi (Kemenristekdikti) terlihat sangat cepat. Salah satu item yang terlihat berkembang misalnya di bidang publikasi yang bergerak cepat menyaingi negara-negara tetangga di lingkup ASEAN. Perkembangan ini tentu saja harus didukung semua pihak yang berada di bawah payung kementerian ini, termasuk Koordinasi Perguruan Tinggi Swasta (Kopertis). Kopertis Wilayah XII Maluku dan Maluku Utara tentunya harus juga membenahi diri dengan berbagai perubahan yang terjadi. Syukurlah, dari keseluruhan (14 wilayah) Kopertis di Indonesia, Kopertis Wilayah XII terkenal di seluruh Indonesia dengan website-nya yang menjadi rujukan dosen-dosen di Indonesia bahkan sampai ke luar negeri. Hal ini penulis cermati, baik lewat perbincangan dengan kalangan dosen di beberapa group facebook, WhatsApp Group, maupun di jejeraing sosial lainnya. Namun, hal ini tentu saja belumlah cukup untuk mengangkat Kopertis Wilayah XII menjadi Kopertis nomor satu di Indonesia. Mimpi menjadi yang terbaik memang harus tetap dimiliki, tetapi mimpi tersebut haruslah ditunjang dengan realitas perencanaan yang matang, sumber daya manusia yang handal, infrastruktur memadai, kemampuan managerial yang mumpuni, serta kedisiplinan penyelenggara di semua tingkatan.

Membicarakan hal-hal terkait mimpi menjadi yang terbaik, tentunya tidak terlepas dari sumbangan pemikiran dari berbagai pihak. Tentunya hal ini juga menjadi tanggung jawab penulis secara pribadi, sekaligus juga sebagai "anak kandung" Kopertis Wilayah XII, Maluku dan Maluku Utara. Baiklah sebagai "anak" penulis mencoba urun rembuk dalam memajukan pendidikan tinggi dalam rumah bersama kita, Kopertis Wilayah XII Maluku dan Maluku Utara. Urun rembuk atau buah pikir ini bukanlah suatu perintah apalagi paksaan, tetapi lebih dimaknai sebagai semacam "keluhan" atau masukan anak kepada bapaknya.

\section{Perkembangan dan Tuntutan Publikasi di Kawasan ASEAN}

Berdasarkan data terkini (8 April 2018), publikasi Indonesia terindeks Scopus pada tahun 2017 tercatat sebanyak 18.931 publikasi, 2 tingkat di bawah Malaysia (31.006 publikasi) dan Singapore (20.740 publikasi). Syukurlah masih di atas Thailand (15.651 publikasi), Viet Nam (6.391 publikasi), dan Philipine (3.150 publikasi). Berdasarkan data paruh pertama 2018, publikasi internasional terindeks Scopus Indonesia di kawasan ASEAN (hanya data tahun 2018), Indonesia 
berada pada posisi kedua dengan 5.163 publikasi, satu tingkat di bawah Malaysia dengan 6.084 publikasi. Posisi ketiga ditempati Singapore dengan 5.062 publikasi, keempat diisi Thailand dengan 3.800 publikasi. Tempat kelima ditempati Viet Nam dengan 2.205 publikasi, dan keenam ditempati Philipines dengan 688 publikasi. (Irawan, D.E. 2018. Data jumlah publikasi 6 negara ASEAN menurut Scopus, url: bit.ly/scopusdataASEAN_08042018).

Data tersebut berubah cepat seiring data yang terus masuk ke pengindeks-pengindeks bereputasi, sebagaimana yang diuanggah Kemenristekdikti dalam bentuk chart pada tanggal 10 April 2018, seperti terlihat di bawah ini. (http://www.mirajnews.com/2018/04/geser-singapuradan-thailand-publikasi-ilmiah-indonesia-peringkat-ke-2-asean.html)

\section{Publikasi Internasional negara-negara ASEAN terindeks pengindeks Global 2018}

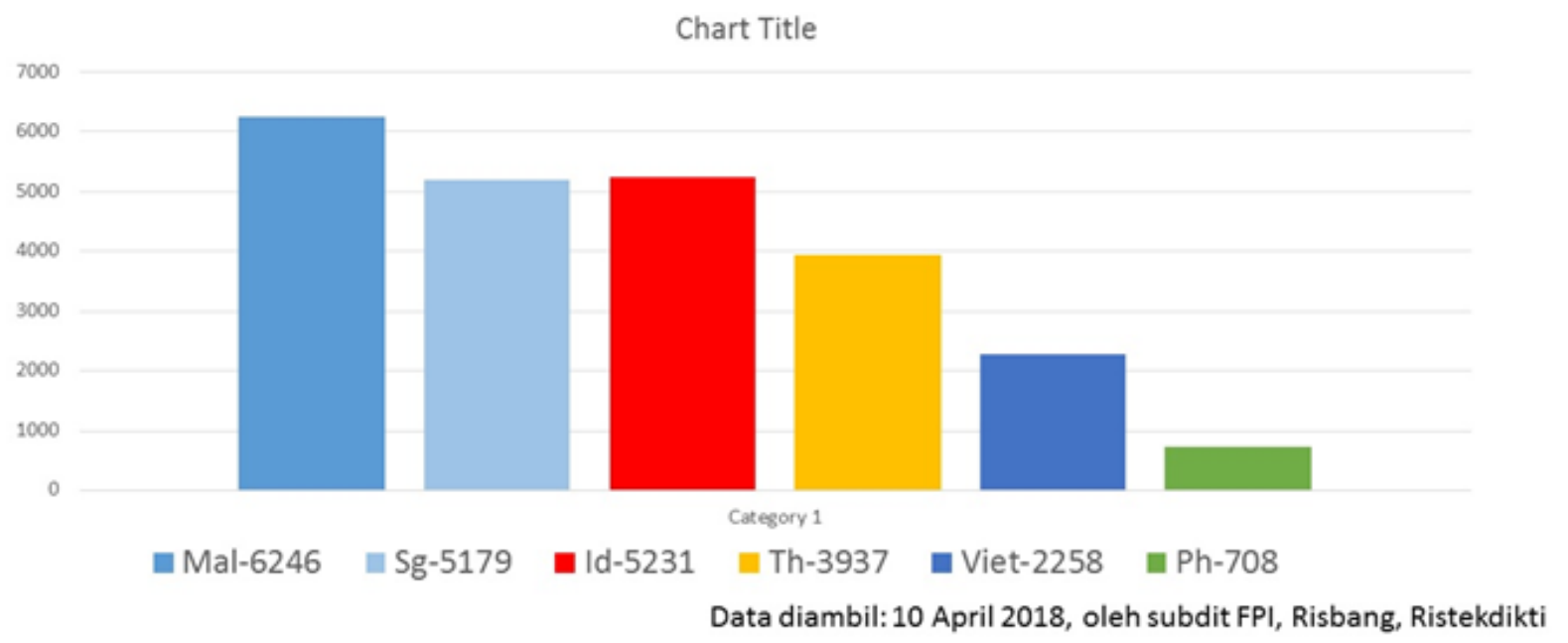

Mencermati dinamika ini tentu saja kita patut bergembira karena apa yang ditargetkan Menristekdikti bahwa pada tahun 2019 jumlah publikasi Indonesia harus melebihi angka 30.000 publikasi akan berakhir sukses, mengingat banyaknya SDM di Indonesia yang potensial terutama jabatan fungsional dosen, peneliti dan mahasiswa S3 yang memiliki kewajiban untuk publikasi internasional sebagai persyaratan kenaikan jenjang jabatan dan kelulusan (Berita Media Ditjen Risbang, 31 Januari 2017).

Yang patut disayangkan adalah, publikasi yang dihasilkan Indonesia lebih banyak berasal dari International Conference ketimbang langsung dari jurnal-jurnal terindeks seperti yang dihasilkan Malaysia dan Singapure. Hal ini menimbulkan polemik yang sering didiskusikan di beberapa WhatsApp Group, dimana kalangan peneliti Indonesia diragukan kemampuannya untuk menembus jurnal-jurnal bereputasi yang terindeks Scopus dan Web of Science (WoS). Hal ini, memang tidak terlalu bermasalah jika yang dikejar Kemenristekdikti adalah jumlah publikasi. Bukankah jumlah publikasi dapat dihasilkan baik dari jurnal maupun konferensi? Bukankah yang dipentingkan di sini adalah menumbuh-kembangkan semangat publikasi, ketimbang dimana mempublikasikannya? Berdasarkan hal inilah maka, keberhasilan Kemenristekdikti memacu dosen-dosen dan para penelitinya untuk mempublikasikan hasil penelitiannya patut diapresiasi.

\section{Peningkatan Kapasitas Perguruan Tinggi Swasta (PTS)}

Menyikapi perjuangan Kemenristekdikti yang dikemukakan sebelumnya, maka pertanyaan pentingnya sekarang adalah: Apa kontribusi Kopertis Wilayah XII Maluku dan Maluku Utara dalam geliat semangat publikasi pada Kemenristekdikti? Berdasarkan hasil penelitian kolaborasi dengan judul: "Faktor-Faktor Yang Mempengaruhi Produktivitas Peneltian Dosen Perguruan 
Tinggi Swasta Di Kopertis Wilayah XII Maluku dan Maluku Utara" yang penulis dan saudara Jusuf Nikolas Anamofa inisiasi, serta melibatkan 30 peneliti lainnya dari 11 PTS di Kopertis XII, terlihat bahwa faktor penghambat terbesar adalah kurangnya biaya penelitian dan publikasi. Faktor penghambat berikutnya adalah kurangnya informasi terkait jurnal dan konferensi bereputasi, serta kurangnya jaringan antar peneliti, serta tidak memedainya perpustakaan yang tersedia.

Berdasarkan beberapa hal di atas, maka sudah sepantasnya jika PTS-PTS dan Kopertis Wilayah XII Maluku dan Maluku Utara menggambil langkah-langkah strategis untuk menyikapinya. Beberapa hal mendasar sekiranya dapat diusulkan untuk menjadi perhatian bersama di kalangan Kopertis Wilayah XII, Maluku dan Maluku Utara, antara lain:

\section{1) Perbanyak Kegiatan Pelatihan Penulisan Artikel Ilmiah Yang Ber-luaran Publikasi Internasional Terindeks.}

Kegiatan pelatihan penulisan artikel nasional maupun internasional memang setiap tahun diagendakan Kemerintekdikti. Namun gaungnya belum terlihat secara nyata di Indonesia. Pelatihan penulisan proposal penelitian juga setiap tahun diagendakan Kopertis Wilayah XII yang diikuti masing-masing PTS dengan mengirimkan utusannya. Tetapi pesertanya, dengan alasan keterbatasan anggaran, setiap tahunnya hanya boleh diikuti oleh 2 orang per PTS. Hasilnya pun belum begitu kelihatan, dikarenakan utusan PTS yang mengikuti kegiatan belum tentu mereka yang siap melaksanakan penelitian ilmiah yang hasilnya nanti berupa temuan-temuan yang siap digunakan atau paling tidak dipublikasikan. Hal lain yang menjadi kelemahan kegiatan ini adalah pada evaluasi kegiatan. Penulis belum pernah membaca evaluasi kegiatan pelatihan penulisan proposal dimana pesertanya dilaporkan sukses mendapat dana Dikti dan mempublikasikan hasilnya di jurnal nasional maupun internasional.

Berdasarkan pengalaman penulis di beberapa group WhatsApp (Misalnya: Peer Tutor Relawan Jurnal Indonesia, Tim Ahli dan Koordinator Relawan Jurnal Indonesia, SCOPUS WoS OSF, Group Jurnal ABDIMAS Indonesia, Komunikasi DPP - DPD Forum Dosen Indonesia, dll.), terlihat bahwa jaringan yang berimbas kolaborasi memegang peranan yang sangat penting dalam budaya meneliti dan mempublikasikan hasil penelitian bersama ke jurnal maupun international conference. Bahkan dapat dikatakan bahwa meningkatnya jurnal-jurnal terakreditasi dan terindeks Directory of Open Access Journal (DOAJ) di Indonesia sangatlah dipengaruhi oleh lahirnya jaringan Relawan Jurnal Indonesia (RJI) tahun 2015 di Yogyakarta. Begitu pun dengan menjamurnya Konferensi Internasional dan publikasi hasil konferensi serta dukungan paper-paper yang mengalir ke konferensi-konferensi tersebut di Indonesia sangatlah dipelopori oleh member group WhatsApp yang disebutkan di atas.

Salah satu hal menarik dari jaringan dan kolaborasi yang mau penulis usulkan adalah pelatihan disertai jaringan kerjasama antar kampus yang disertai MoU dengan publisher yang terindeks sehingga luaran hasil pelatihan dapat langsung dipublikasikan. Publikasi ini baik pada jurnal nasional terakreditasi maupun jurnal internasional atau prosiding terindeks. Hal ini akan berdampak besar bagi peningkatan publikasi dosen-dosen di Kopertis Wilayah XII agar tidak ketinggalan dengan geliat yang telah terjadi di wilayah lain, terutama di pulau Jawa dan Sumatera.

Perguruan Tinggi Swasta (PTS) di Kopertis Wilayah XII Maluku dan Maluku Utara sudah saatnya "dipaksa" untuk meningkatkan kapasitasnya dalam menyikapi perkembangan ini. PTS harus diperkuat bukan hanya pada darma pendidikan dan pengajaran tetapi juga pada penelitian dan pengabdian kepada masyarakat yang berujung pada produk dan publikasi ilmiah. PTS sudah sepantasnya dilarang berdalih kekurangan biaya dan lain sebagainya, karena sebagian besar dosennya telah menerima tunjangan sertifikasi yang diperuntukkan untuk tujuan penelitian dan publikasi. Anggaran untuk berkolaborasi antar PTS pun tergolong tidak besar. Cukup dengan 1020 juta rupiah per PTS (minimal 5 PTS), satu kegiatan pelatihan atau whorkshop penulisan artikel ilmiah berujung publikasi terindeks dapatlah terlaksana. Prinsip dimana ada kemauan di situ ada jalan harusnya dijiwai dalam kegiatan-kegiatan seperti ini.

2) Pelatihan Teknis Menyiasati Syarat Pengajuan Proposal PPM di Simlitabmas 
Menyikapi tekanan terhadap PTS di atas, maka sudah selayaknya Kopertis Wilayah XII Maluku dan Maluku Utara mengambil peran sebagai pengayom yang menunjang tujuan ini. Salah satu contoh konkrit yang perlu segera dilakukan Kopertis Wilayah XII adalah mengadakan pelatihan teknis menyiasati pengajuan proposal di Simlitabmas Ristekdikti, karena tidak semua PTS memiliki sumber dana untuk membiayai proposal penelitian dosen sehingga mereka harus bersaing secara nasional.

Pelatihan teknis yang penulis maksudkan adalah yang terkait dengan hal-hal mendasar seputar pemahaman dosen dalam menyusun sebuah proposal yang layak dinilai di tingkat nasional. Beberapa kali penulis mengadakan pelatihan dasar penunjang penulisan proposal (terkait teknis proposal dan pendukung seperti literatur yang dipakai, software penunjang sitasi, open science framework sebagai penunjang data Google Scholar yang berakhir di CV Author di SINTA Ristekdikti, template artikel ilmiah, dll.,) di Universitas Halmahera (UNIERA) Tobelo, Universitas Kristen Indonesia Maluku (UKIM) Ambon, dan terakhir di Universitas Nuku (UNNU) Tidore, terlihat bahwa hal-hal teknis ini menjadi kendala yang cukup "mematikan" semangat para dosen. Hal ini perlu disikapi serius oleh teman-teman di Kopertis Wilayah XII Maluku dan Maluku Utara.

Pelatihan seperti ini sudah sepantasnya dilakukan karena beberapa contoh yang penulis sebutkan di atas akan sangat berpengaruh baik pada saat penulisan proposal penelitian, maupun pada saat menulis artikel sebagai luaran dari penelitian yang dilakukan. Hal ini juga menjawab tuntutan publikasi dimana jurnal-jurnal ilmiah maupun paper konferensi nasional dan internasional mensyarakatkan menggunakan software dan template baku penulisan yang terstandarisasi.

\section{3) Pendampingan Berbasis Sumber Daya Lokal Kawasan}

Beberapa waktu lalu penulis berkunjung ke Universitas Nuku di Tidore merespons undangan tidak resmi dari Dekan Fakultas Pertanian untuk sekedar berdiskusi. Dalam kapasitas sebagai Ketua Forum Dosen Indonesia Provinsi Maluku Utara, penulis kemudian berbagi bersama sivitas akademika Universitas Nuku terkait beberapa hal, antara lain hal-hal teknis perubahan pada Buku Panduan PPM Edisi XII serta perubahan penginputan proposal pada Simlitabmas 2018, juga tentang bagaimana menyiasati ribetnya CV pengusul hibah yang akan "ditarik" dari data SINTA yang ujung-ujungnya mensyaratkan membuat akun Google Scholar yang mensyaratkan juga memiliki email berdomain institusi dosen yang bersangkutan. Hal lainnya yang dibagi adalah cara membuat artikel singkat dan mempublikasikannya pada open science framework (OSF) serta cara menggunakan software mendeley pada tataran dasar untuk sitasi dan penulisan daftar pustaka secara otomatis.

Hal-hal seperti ini belum pernah ditemukan penulis pada pelatihan-pelatihan yang diselenggarakan Ristekdikti maupun Kopertis Wilayah XII. Mengapa demikian? Mungkin saja jawabannya adalah para pimpinan di level Ristekdikti dan Kopertis merasa para dosen sudah menguasai hal-hal ini. Tetapi apa yang terjadi? Sebagian besar dosen belum familiar dengan halhal seperti ini dan membutuhkan pendampingan secara mendalam. Hal ini memerlukan perhatian serius Kopertis Wilayah XII dan saran penulis: pakailah pendamping-pendamping kawasan dari dosen-dosen setempat untuk menjadi penggerak dan pelatih di lapangan. Dengan menggerakkan tenaga-tenaga lapangan yang ada di sekitar PTS-PTS di wilayah ini, penulis yakin hal-hal seperti ini akan tertangani dengan baik, ketimbang melaksanakan pelatihan skala Ristekdikti yang jangankan diterakpan, disosialisasikan hasilnya pun tidak pernah oleh mereka yang mengikuti pelatihan itu.

\section{Kolaborasi atau Kolaps (Catatan Penutup).}

Ini sudah jaman kolaborasi bukan lagi persaingan yang tidak sehat. Kolaborasi atau kolaps sewajarnya menjadi semboyan PTS-PTS yang mau memajukan dirinya sehingga kerjasama apapun akan terwujud dengan tidak sungkan. Beberapa contoh kolaborasi yang dapat dilakukan PTS-PTS di Maluku dan Maluku Utara, misalnya Joint International Conference Terindeks, Joint 
Penelitian Berbasis Kawasan, Joint Pelatihan dan Whorkshop Artikel yang hasilnya dipublikasikan pada Publisher terindeks, dan lain sebagainya.

Kolaborasi antar PTS di Maluku dan Maluku Utara sudah sewajarnya didorong oleh Kopertis Wilayah XII sehingga akan berdampak pada kemajuan bersama. Pertukaran dan keterbukaan informasi juga sudah sewajarnya dilakukan mulai dari tingkat penyelenggara Kopertis sampai ke level prodi di PTS. Bukankah Kemenristekdikti juga dalam berbagai sistem online-nya telah melaksanakan program keterbukaan informasi. Ke depan, Kopertis akan berubah menjadi Lembaga Layanan Pendidikan Tinggi dan akan diserahkan beberapa kewenangan termasuk pengelolaan Penelitian Dosen Pemula (PDP). Hal ini pun akan membutuhkan keterbukaan informasi sehingga dapat membantu dosen-dosen pemula memulai risetnya.

Bersyukur sekali belakangan ini terlihat bahwa informasi-informasi terkait penelitian dan pengabdian kepada masyarakat dari Kopertis Wilayah XII telah secara cepat tersalur dengan adanya WhatsApp Group Penelitian Kopertis Wilayah XII. Semoga hal ini dapat terus dijaga dan dikembangkan ke bagian-bagian lainnya dalam mempermudah pelayanan kepada PTS di wilayah kerja Kopertis Wilayah XII Maluku dan Maluku Utara.

Berbagai kerjasama di tingkat PTS yang diprakarsai Kopertis sudah sewajarnya dipikirkan mulai sekarang demi menjawab tantangan perubahan yang terjadi dalam dunia pendidikan tinggi kita belakangan ini. Bekerjasamalah jika tidak ingin dilindas oleh perubahan yang bergerak cepat. Bukankah maju bersama itu lebih baik daripada maju sendiri tetapi memiliki banyak musuh? Mari bergandeng tangan dan maju bersama di bawah payung Kopertis Wilayah XII, Maluku dan Maluku Utara. 